Biogeosciences Discuss., doi:10.5194/bg-2015-662, 2016

Manuscript under review for journal Biogeosciences

Published: 10 February 2016

(c) Author(s) 2016. CC-BY 3.0 License.

\title{
Soil greenhouse gases emissions reduce the benefit of mangrove plant to mitigating atmospheric warming effect
}

\author{
Guangcheng Chen ${ }^{1}$, Bin Chen $^{1}$, Dan $\mathrm{Yu}^{2}$, Yong $\mathrm{Ye}^{2}$, Nora F.Y. Tam ${ }^{3}$, Shunyang Chen ${ }^{1}$ \\ ${ }^{1}$ Third Institute of Oceanography, State Oceanic Administration, Xiamen, Fujian, 361005, China \\ $5{ }^{2}$ Key Laboratory of the Ministry of Education for Coastal and Wetland Ecosystems, Xiamen University, Xiamen, Fujian, \\ 361102, China \\ ${ }^{3}$ Department of Biology and Chemistry, City University of Hong Kong, Hong Kong SAR, China
}

Correspondence to: G. Chen (gc.chen@ tio.org.cn)

10 Abstract

Mangrove soils have been recognized as sources of atmospheric greenhouse gases but the atmospheric fluxes are poorly characterized, and their adverse warming effect has scarcely been considered with respect to the role of mangrove wetlands in mitigating global warming. The present study balanced the warming effect of soil greenhouse gas emissions with plant carbon dioxide $\left(\mathrm{CO}_{2}\right)$ sequestration rate in a highly productive mangrove wetland in South China to assess the role of

15 mangrove wetland in mitigating atmospheric warming. The results showed that mangrove soils were significant sources of greenhouse gases, and the fluxes were significantly higher in summer and also different among mangrove sites. Gases fluxes were positively correlated with the soil organic carbon, total nitrogen, and $\mathrm{NH}_{4}{ }^{+}-\mathrm{N}$ contents. The mangrove plant was able to sequester a considerable amount of atmospheric $\mathrm{CO}_{2}$ at $5930 \mathrm{~g} \mathrm{CO}_{2} \mathrm{~m}^{-2} \mathrm{yr}^{-1}$ in the present study, and the ecosystem was source of methane $\left(\mathrm{CH}_{4}\right)$ and nitrous oxide $\left(\mathrm{N}_{2} \mathrm{O}\right)$ gases but more intense $\mathrm{CO}_{2}$ sink. However, the warming effect of soil gas emissions, equivalent to $1222 \mathrm{~g} \mathrm{CO}_{2} \mathrm{~m}^{-2} \mathrm{yr}^{-1}$, was able to offset a large proportion ( 22\%) of plant $\mathrm{CO}_{2}$ sequestration, and the two trace gases comprised $\sim 24 \%$ of the total warming effect. We therefore propose the assessment of the direct mitigation of atmospheric warming by mangrove ecosystem that should take into account both soil greenhouse gases emissions and plant $\mathrm{CO}_{2}$ sequestration.

\section{Introduction}

25 The global atmospheric concentrations of greenhouse gases, carbon dioxide $\left(\mathrm{CO}_{2}\right)$, and other two trace gases, methane $\left(\mathrm{CH}_{4}\right)$ and nitrous oxide $\left(\mathrm{N}_{2} \mathrm{O}\right)$ have all shown large increases since the pre-industrial times and cause the global warming problems. The atmospheric concentrations of $\mathrm{CO}_{2}, \mathrm{CH}_{4}$ and $\mathrm{N}_{2} \mathrm{O}$ have increased from $278 \mathrm{ppm}$ in 1750 to $391 \mathrm{ppm}$ in 2011, by a factor of 2.5 from $722 \mathrm{ppb}$ to $1803 \mathrm{ppb}$, and from $270 \mathrm{ppb}$ to $342 \mathrm{ppb}$, respectively (IPCC, 2014a). $\mathrm{CO}_{2}$ concentration is increasing at the fastest observed decadal rate of change in the past ten years and unfortunately the atmospheric greenhouse gas concentrations continue to rise. In order to maintain global temperature warming below $2^{\circ} \mathrm{C}$ over the $21^{\text {st }}$ century relative to 
Biogeosciences Discuss., doi:10.5194/bg-2015-662, 2016

Manuscript under review for journal Biogeosciences

Published: 10 February 2016

(c) Author(s) 2016. CC-BY 3.0 License.

pre-industrial levels, a reduction by $40 \%$ to $70 \%$ of global anthropogenic greenhouse gases emissions by 2050 compared to 2010, and increasing the existing biological carbon pools for carbon sequestration have been proposed (IPCC, 2014a).

Mangroves grow along the coastlines of most of the world's tropical and subtropical regions. Despite the limited area occupied by mangrove wetlands compared to terrestrial forests, these highly productive ecosystems are ecologically 5 important on a global scale, and have been suggested to be responsible for $10 \%$ of global terrestrial carbon export to the ocean and $\sim 10 \%$ of the global oceanic burial of carbon (Duarte et al., 2005; Dittmar et al., 2006). Recent studies have also highlighted the valuable role played by mangrove wetlands in carbon sequestration, and estimated the carbon burial rate in mangrove soil as $226 \mathrm{~g} \mathrm{C} \mathrm{m}^{-2} \mathrm{yr}^{-1}$ from 34 sites (Mcleod et al., 2011). Plants sequester $\mathrm{CO}_{2}$ from the atmosphere through photosynthesis and store it in their biomass. The capability of mangrove plants to sequester atmospheric $\mathrm{CO}_{2}$ is therefore

10 related to their net primary production (NPP). The overall global mangrove NPP, recently estimated by Bouillon et al. (2008), is $1362.5 \mathrm{~g} \mathrm{C} \mathrm{m}^{-2} \mathrm{yr}-1$, i.e. $4996 \mathrm{~g} \mathrm{CO}_{2} \mathrm{~m}^{-2}$ is directly captured by mangrove plants each year.

Being inter-tidal, mangrove wetlands are regularly flooded by incoming tides, and their soils altering between oxic and anoxic conditions, favor microbial processes like nitrifcation, denitrification and methanogenesis that produce greenhouse gases. Numerous studies have recognized mangrove soil as sources of atmospheric greenhouse gases (Allen et al., 2007;

15 Chauhan et al., 2008; Chen et al., 2010). The biogenic emission of greenhouse gases from mangrove soil to the atmosphere could be further enhanced by anthropogenic nitrogen input (Purvaja and Ramesh, 2001; Muñoz-Hincapié et al., 2002; Kreuzwieser et al., 2003; Chen et al., 2011). These gas emissions contribute to atmospheric warming and reduce the overall mitigation of global warming by mangroves. Therefore, the role that mangrove wetlands play in directly mitigating atmospheric warming is reflected by the exchange of greenhouse gases between the mangrove ecosystem and the atmosphere.

20 Assessments of the direct effect of mangrove wetlands, on the ecosystem scale, in mitigating atmospheric warming, are important but still lacking. Although some studies have focused on the net ecosystem production (NEP) that combined the net primary production and gaseous carbon emissions from soil respiration (Golley et al., 1962; Komiyama, 2008) in mangrove wetlands, for assessing the contribution of mangrove wetlands to atmospheric carbon gas exchange on the ecosystem scale, these studies are inadequate for assessing the contribution of mangroves to mitigating atmospheric warming,

25 as the contributions of $\mathrm{N}_{2} \mathrm{O}$ emission and the warming effect of gases emissions were not taken into account.

On the global scale, the mean soil $\mathrm{CO}_{2}-\mathrm{C}$ flux represents $\sim 20 \%$ of the mangrove NPP in a carbon budget quantified by Bouillon et al. (2008); this indicates that the soil $\mathrm{CO}_{2}$ emission from mangrove wetland reduces $20 \%$ of the $\mathrm{CO}_{2}$ sequestration rate by mangrove plant. In addition, although the atmospheric fluxes of $\mathrm{CH}_{4}$ and $\mathrm{N}_{2} \mathrm{O}$ are generally 2 or 3 orders of magnitude lower than $\mathrm{CO}_{2}$ flux in mangrove wetlands (Chen et al., 2010), their contributions to global warming

30 could also be relevant and are worthy attention, because these two gases are more stable and have considerably higher radioactive forcing than $\mathrm{CO}_{2}$, with direct global warming potential (GWP) 298 and 34 times, respectively, as that of $\mathrm{CO}_{2}$ (Myhre et al., 2013). However, the greenhouse gases emissions from mangrove soils remain poorly characterized, and few studies have considered the warming effect of the simultaneous emissions of the three aforementioned gases from mangrove soils when evaluating the role of mangrove ecosystems in mitigating global warming. 
Biogeosciences Discuss., doi:10.5194/bg-2015-662, 2016

Manuscript under review for journal Biogeosciences

Published: 10 February 2016

(c) Author(s) 2016. CC-BY 3.0 License.

In this study, spatial and seasonal variations in soil greenhouse gases emissions were investigated in a highly productive mangrove wetland in South China; the warming effect of the gases emissions was quantified and then balanced with the plant $\mathrm{CO}_{2}$ sequestration rate to estimate the mitigating effect of mangrove wetland on atmospheric warming. We also evaluated the effects of soil characteristics on greenhouse gases emissions. We hypothesized that mangroves may be

5 ecologically important in sequestration of atmospheric $\mathrm{CO}_{2}$ and mitigation of global warming but that the greenhouse gas emissions from mangrove soil might also be significant and would largely offset any benefits. In addition, the contributions of the two trace gases, $\mathrm{N}_{2} \mathrm{O}$ and $\mathrm{CH}_{4}$, to warming might be relevant and were considered.

\section{Materials and Methods}

\subsection{Study area}

10 Soil greenhouse gases emissions and plant $\mathrm{CO}_{2}$ sequestration rates were studied in a subtropical mangrove area in the Jiulong River Estuary in southern China. The region is subtropical (mean annual temperature: $20.9{ }^{\circ} \mathrm{C}$ ), with most of the annual rainfall $(1284 \mathrm{~mm})$ derived from summer typhoons. Tides are semi-diurnal, with an average range of $4 \mathrm{~m}$. Most forests ( $32 \mathrm{ha})$ in this area are located on the southwestern shore, with Kandelia obovata as the dominant canopy species. The mangrove soils are mainly composed of silt and clay (Alongi et al., 2005).

15 Samplings were carried out in three mangrove sites (Fig. 1) located at Caoputou Village (24²3'40.89"N, 11754'42.90"E) and Xiaguo Village $\left(24^{\circ} 23^{\prime} 36.24^{\prime \prime} \mathrm{N}, 117^{\circ} 55^{\prime} 19.48^{\prime \prime E}\right)$ and on Haimen Island $\left(24^{\circ} 24^{\prime} 24.05^{\prime \prime N}, 1^{\circ} 56^{\prime} 28.51^{\prime \prime E}\right)$. The width of each sampling area was $\sim 40 \mathrm{~m}, \sim 90 \mathrm{~m}$ and $\sim 90 \mathrm{~m}$ from the landward to seaward fringes in the three mangrove sites, respectively. Caoputou (CPT) mangrove was a rehabilitated $K$. obovata forest located in the high intertidal zone on the south bank of the estuary, and this mangrove had the highest canopy height $(7.8 \mathrm{~m})$. Xiaguo (XG) mangrove was located in the

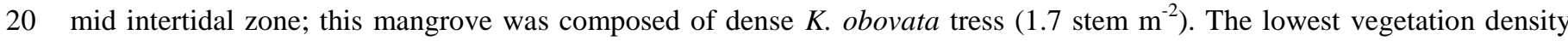
(0.9 stem $\left.\mathrm{m}^{-2}\right)$ and canopy height $(5.5 \mathrm{~m})$ occurred in the natural mangrove on Haimen Island (HMI). Salinity of the soil porewater, measured using a pocket refractometer (0-100 parts per thousands, Atago PAL-06 S, Japan) was 11, 11 and 14 in the three mangrove forest, respectively.

\section{$25 \quad 2.2$ Soil to atmosphere greenhouse gases fluxes}

Soil to atmosphere fluxes of greenhouse gases were quantified in January, April, August and October 2012, representing the seasons winter, spring, summer and autumn, respectively. All sampling was conducted two hours before the lowest ebb tide during the daytime as the study areas are subject to semi-diurnal tides, and the exposure times of mangrove wetlands are relative short. Nine replicate plots were chosen at each of the three mangrove sites during each sampling campaign to

30 achieve more accurate estimation of gas emissions because great spatial variation is a characteristic of gas flux, even on a small scale (Allen et al., 2007; Chen et al., 2010). 
Biogeosciences Discuss., doi:10.5194/bg-2015-662, 2016

Manuscript under review for journal Biogeosciences

Published: 10 February 2016

(c) Author(s) 2016. CC-BY 3.0 License.

To measure the soil to atmosphere fluxes of greenhosue gases, some studies in salt marshes rest the gas chamber on the collar that has been permanently inserted into the surface sediment to collect the gases (e.g. Magenheimer et al. 1996, Moseman-Valtierra et al. 2011). In these studies, the chambers are generally large and the intact live marsh plants or plant community are covered within the chambers, so the pre-installed collar could be helpful to achieve enclosed airtight space

5 and avoid the disturbance from inserting the large chamber. However, most studies on gas flux measurements in mangroves employed a smaller chamber (e.g. with an internal volume of $\sim 1 \mathrm{~L}$ ) than that applied in saltmarshes, and the chamber was directly inserted into the sediment that was also softer (e.g. Corredor et al., 1999; Bauza et al., 2002; Allen et al., 2007; Chen et al., 2012). Moreover, unlike saltmarsh, the studies in mangrove forest quantify the fluxes between sediment and atmosphere; therefore, the chamber covers only sediment and is smaller. The single-chamber method similar to that used in mangroves has also been employed in saltmarshes (Morries and Whiting, 1986; Adams et al. 2012).

Gas flux in this study was quantified using the static (closed) chamber technique followed by gas chromatography as described by Chen et al. (2010). The chambers had an area of $0.025 \mathrm{~m}^{2}$ and an internal volume of 1.251 , which is similar to those used by previous researchers (e.g. Corredor et al., 1999; Bauza et al., 2002). They stated that the volume/basal area ratio of the chamber was easy for deployment and sufficiently small for the rapid increase in gas concentrations, but large enough to minimize disturbance of the enclosed sediment surface. Therefore, no additional device like electric fan was installed to stir the air inside the chamber in their studies and the present study. Chen et al. (2010) further revealed that gases continuously released and their concentrations linearly related with the deployment time, indicating that this static chamber is suitable for the sampling. The open end of the chamber was inserted $3 \mathrm{~cm}$ into the soil. Chambers were placed in locations without mangrove seedlings, aboveground roots or litter fall to avoid the influences of these factors on gas fluxes, and the 20 deployment time was set to 30 minutes, with sampling at 10-minute intervals. At each sampling time, a 5-ml gas sample was collected with a hypodermic needle attached to a 10-ml glass syringe from the chamber and then injected into a $20-\mathrm{ml}$ gas sampling bag. Gas concentrations were analyzed in parallel with a gas chromatography system (7890A, Agilent Technologies, Santa Clara, California, USA) configured with a single channel and two detectors, by comparing the peak areas of samples against an Agilent Greenhouse Gas Checkout Sample (1 ppm $\mathrm{N}_{2} \mathrm{O}, 5$ ppm $\mathrm{CH}_{4}$ and 600 ppm $\mathrm{CO}_{2}$ in $\mathrm{N}_{2}$ ).

25 The $\mathrm{N}_{2} \mathrm{O}$ and $\mathrm{CH}_{4}$ concentrations were determined with a 63Ni electron capture detector and a flame ionization detector (FID), respectively. The $\mathrm{CO}_{2}$ concentration was analyzed by FID after methanization. During measurement, the standard sample was analyzed in every 15-20 samples to ensure the data quality. The relative standard deviations of replicate standard measurements were $3.6 \%, 2.5 \%$ and $3.4 \%$ for $\mathrm{N}_{2} \mathrm{O}, \mathrm{CH}_{4}$ and $\mathrm{CO}_{2}$, respectively.

The soil to atmosphere fluxes of greenhouse gases were calculated from the following formula:

$$
F_{m}=V \Delta M / A \rho
$$

where $F_{m}$ is the interfacial gas flux $\left(\mathrm{mol} \mathrm{m} \mathrm{m}^{-2} \mathrm{~h}^{-1}\right), V$ is the internal air volume $\left(\mathrm{m}^{3}\right)$ in the chamber after being placed, $\Delta M\left(\mathrm{~h}^{-1}\right)$ is the change in gas concentration in the container, $A$ is the surface area of the soil $\left(\mathrm{m}^{2}\right)$ and $\rho$ is the volume of per mol gas $\left(\mathrm{m}^{3} \mathrm{~mol}^{-1}\right)$. During each sampling, the open air temperature was simultaneously measured with a mercury thermometer to calculate the $\rho$ value. 
Biogeosciences Discuss., doi:10.5194/bg-2015-662, 2016

Manuscript under review for journal Biogeosciences

Published: 10 February 2016

(c) Author(s) 2016. CC-BY 3.0 License.

Although $\mathrm{CO}_{2}$ emissions from sediment include the $\mathrm{CO}_{2}$ efflux from plant roots and heterotrophic respiration, the chambers used for flux measurement were placed in locations without aboveground roots, and the $\mathrm{CO}_{2}$ flux measured in this study can be attributed to soil heterotrophic respiration because most metabolic respiration from underground roots is released through lenticels and the flux obtained using static chambers would be close to the levels of $\mathrm{CO}_{2}$ released due to soil

5 respiration (Tomlinson, 1986). The gas fluxes were converted to $\mathrm{CO}_{2}$-equivalent fluxes to indicate their respective contributions to global warming using the GWP value of each gas $\left(1,34\right.$ and 298 for $\mathrm{CO}_{2}, \mathrm{CH}_{4}$ and $\mathrm{N}_{2} \mathrm{O}$, respectively, over a 100-year timeframe) according to Myhre et al. (2013).

\subsection{Sampling and analysis of soil}

Soil parameters were also measured at these sampling sites in summer to check their relationship with gases fluxes. Soil

10 redox potential (Eh) under the chamber was measured using a pH/Eh meter (WP-81, TPS, Australia) after gas sampling, by inserting the platinum probe directly into the soil at a depth of $5 \mathrm{~cm}$ from the surface. Independent soil cores to a depth of 15 $\mathrm{cm}$ (6 cores for each mangrove site) were then collected using hand-held PVC corers. Soil organic carbon (OC) concentration was analyzed using rapid dichromate oxidation procedure. Total Kjeldahl nitrogen (TKN) content after Kjeldahl digestion and $\mathrm{NH} 4+-\mathrm{N}$ and $\mathrm{NO} 3--\mathrm{N}$ contents in the $\mathrm{KCl}(2 \mathrm{M})$ extracts were measured by the Continuous Flow

15 Analyzer (CFA, Futura II, Alliance Instruments). All soil analyses were based on the standard methods for soil analyses described by Page et al. (1982), and data were expressed in terms of $105^{\circ} \mathrm{C}$ oven-dried weight.

\subsection{Plant $\mathrm{CO}_{2}$ sequestration rate}

Plant $\mathrm{CO}_{2}$ sequestration rate was calculated from the NPP, the carbon content and the formula weights of $\mathrm{CO}_{2}$ and $\mathrm{C}$. Mangrove NPP was estimated using the litter fall technique proposed by Teas (1979), which postulates that 1/3 of the NPP is

20 returned as litter fall. A global extrapolation also showed a clear relationship between litter fall and wood production and further suggested that litter production amounts to $\sim 32 \%$ of the total mangrove NPP including root production (Bouillon et al., 2008). This rapid and direct method was also applied in other studies (e.g. Lee, 1990; Alongi, 2009), but its accuracy depends on the availability of a good conversion factor (Odum et al., 1982). In this study, a conversion factor 2.75 was applied for the estimation of NPP, which was calculated from the previous reported NPP (including root production) and the concurrent litter fall production for K. obovata mangrove in the Jiulong River Estuary (Lin et al., 1985). The mean carbon content in various plant fractions was $47 \%$ for $K$. obovata in the Jiulong River Estuary (Zheng et al., 1995).

Litter fall samples were collected using metal-framed litter traps $(\Phi=70 \mathrm{~cm}$ for surface area, $30 \mathrm{~cm}$ depth) with $2-\mathrm{mm}$ mesh. Nine traps were placed randomly at similar height above the maximum tide level (1.5m above the sediment) in each mangrove site, under canopies. Trap contents were collected monthly and sorted into the categories of leaves, wood, flowers and propagules and were then dried at $60{ }^{\circ} \mathrm{C}$ to a constant weight and weighed. 
Biogeosciences Discuss., doi:10.5194/bg-2015-662, 2016

Manuscript under review for journal Biogeosciences

Published: 10 February 2016

(c) Author(s) 2016. CC-BY 3.0 License.

\subsection{Statistical analysis}

The normality of variables was checked using the Kolmogorov-Smirnov test, and those that did not follow a normal distribution were transformed to improve normality and homoscedasticity prior to analysis. Two-way ANOVA was used to test differences in greenhouse gas flux among the four seasons and the three sites. If the difference was significant $(\mathrm{p}<0.05)$,

5 a post hoc Tukey test was used to determine the differences. Differences in litter fall production and soil characteristics among different mangroves were compared by one-way ANOVA. Pearson correlation coefficients were calculated to determine the relationships between soil properties and greenhouse gas fluxes in summer. All statistical analyses were performed using SPSS 18.0 for Windows (SPSS Inc., USA).

\section{Results}

\section{$10 \quad 3.1$ Soil to atmosphere greenhouse gas fluxes}

The soil to atmosphere greenhouse gas fluxes ranged from -1.6 to $50.0 \mu \mathrm{g} \mathrm{m}^{-2} \mathrm{~h}^{-1},-1.4$ to $3215.3 \mu \mathrm{g} \mathrm{m}^{-2} \mathrm{~h}^{-1}$ and -31 to 512 $\mathrm{mg} \mathrm{m}^{-2} \mathrm{~h}^{-1}$, for $\mathrm{N}_{2} \mathrm{O}, \mathrm{CH}_{4}$ and $\mathrm{CO}_{2}$, respectively, in the three mangrove wetlands in Jiulong River Estuary (Fig. 2). The annual emissions of $\mathrm{N}_{2} \mathrm{O}, \mathrm{CH}_{4}$ and $\mathrm{CO}_{2}$ from soil were then estimated to be $0.18 \mathrm{gN}_{2} \mathrm{O} \mathrm{m}^{-2} \mathrm{yr}^{-1}, 7.0 \mathrm{~g} \mathrm{CH}_{4} \mathrm{~m}^{-2} \mathrm{yr}^{-1}$ and 931.0 $\mathrm{gCO}_{2} \mathrm{~m}^{-2} \mathrm{yr}^{-1}$, respectively.

15 The $\mathrm{N}_{2} \mathrm{O}$ fluxes were found to vary significantly among the three mangrove sites $(\mathrm{F}=10.63, \mathrm{p}=0.000)$ and among the four seasons $(\mathrm{F}=17.21, \mathrm{p}=0.000)$ according to two-way ANOVA test; however, no significant interaction was found between these two factors $(\mathrm{F}=1.28, \mathrm{p}>0.05)$. XG mangrove had higher $\mathrm{N}_{2} \mathrm{O}$ flux than the other two sites, which had similar fluxes. The highest $\mathrm{N}_{2} \mathrm{O}$ flux was measured in summer, while the lowest was in the winter and autumn.

Both mangrove site $(\mathrm{F}=15.36, \mathrm{p}=0.000)$ and season $(\mathrm{F}=26.03, \mathrm{p}=0.000)$ had significant effects on $\mathrm{CH}_{4}$ flux, and

20 significant effect of the interaction between the two factors was also found on the gas fluxes $(\mathrm{F}=3.83, \mathrm{p}=0.000)$. No significant difference was measured in spring, but the gas fluxes were variable in other seasons. Higher $\mathrm{CH}_{4}$ flux was found at CPT mangrove in winter, but was at XG in autumn. In summer, $\mathrm{XG}$ and CPT had comparable $\mathrm{CH}_{4}$ fluxes, higher than that measured at HMI. The gas fluxes were found to be lowest in winter and spring in CPT and XG sties and highest in the summer. For HMI, significantly higher $\mathrm{CH}_{4}$ flux was also measured in summer, with lowest flux found in winter.

For $\mathrm{CO}_{2}$, the flux also varied significantly among the mangrove sites $(\mathrm{F}=10.24, \mathrm{p}=0.000)$ and seasons $(\mathrm{F}=73.25, \mathrm{p}=0.000)$, and the interaction between these two factors was also significant $(\mathrm{F}=4.42, \mathrm{p}=0.001) . \mathrm{CO}_{2}$ fluxes were comparable among the three mangrove sites in winter, while HMI site had the lowest gas fluxes in the three seasons. Higher fluxes were recorded in CPT (in spring and summer) or XG (in summer and autumn) mangroves. Among the four seasons, the highest $\mathrm{CO}_{2}$ fluxes were found in summer, irrespectively the mangrove sites, with autumn fluxes following (except CPT). 
Biogeosciences Discuss., doi:10.5194/bg-2015-662, 2016

Manuscript under review for journal Biogeosciences

Published: 10 February 2016

(c) Author(s) 2016. CC-BY 3.0 License.

\subsection{Soil characteristic and their relationship with gases fluxes}

Soil characteristics except $\mathrm{NO}_{3}{ }^{-}-\mathrm{N}$ concentration and $\mathrm{E}_{\mathrm{h}}$ significantly varied among the three mangrove sites in Jiulong River Estuary (Fig. 3). Lower soil water content was measured in CPT than in other two sites (p<0.01). Soil $\mathrm{NH}_{4}{ }^{+}-\mathrm{N}$ content was lower in CPT and HMI ( $<<0.05)$. XG mangrove site had the highest soil OC and TKN concentrations while the lowest concentrations were measured at HMI. Among the measured soil parameters, $\mathrm{NH}_{4}{ }^{+}-\mathrm{N}, \mathrm{OC}$ and TKN concentrations were positively correlated with fluxes of the three gases (Table 1), but no significant effect was detected for other soil parameters on the gases fluxes.

\subsection{Litter fall and net primary productions}

This study measured high litter fall productions of the subtropical mangroves (771-1565 $\mathrm{gDW} \mathrm{m}^{-2} \mathrm{yr}^{-1}$ ), and the mean total

10 production was $1251 \mathrm{gDW} \mathrm{m}^{-2} \mathrm{yr}^{-1}$ in Jiulong River Estuary (Table 2). Leaf fall and reproduction components were 550 and $514 \mathrm{gDW} \mathrm{m}^{-2} \mathrm{yr}^{-1}$, comprising $44 \%$ and $41 \%$, respectively, of the total litteral production. The present study also measured a lower litter fall production in the HMI mangrove site compared to the other two mangrove sites due to its lower leaf and twig production. Using the conversion factor 2.75 , the net primary production of mangrove calculated from litter fall production was $3441 \mathrm{gDW} \mathrm{m}^{-2}$ in the Jiulong River Estuary, equivalent to $1617 \mathrm{~g} \mathrm{C} \mathrm{m}^{-2} \mathrm{yr}^{-1}$. Greatly spatial variation was found among the three mangrove sites, and the CPT mangrove had twice production as high as that of HMI mangrove.

\subsection{Mitigating effect of the mangrove ecosystem on atmospheric warming}

In case of high primary productions and low soil carbon gas emissions, the mangrove wetlands in this study had high NEP rates ranging from 912 to $1746 \mathrm{~g} \mathrm{C} \mathrm{m}^{-2} \mathrm{yr}^{-1}$ (Table 3), with a mean as $1358 \mathrm{~g} \mathrm{C} \mathrm{m}^{-2} \mathrm{yr}^{-1}$. The carbon gas emission accounted for $16 \%$ of the total mangrove NPP, and the $\mathrm{CH}_{4}$ made a negligible contribution $(0.2 \%-3.4 \%)$ to the total carbon gas emission.

With both plant $\mathrm{CO}_{2}$ sequestration (Table 3) and soil gas emissions combined, the net ecosystem exchanges of greenhouse gases were $0.15 \mathrm{~g} \mathrm{~N}_{2} \mathrm{O} \mathrm{m}^{-2} \mathrm{yr}^{-1}, 1.91 \mathrm{~g} \mathrm{CH}_{4} \mathrm{~m}^{-2} \mathrm{yr}^{-1}$ and $-6405 \mathrm{~g} \mathrm{CO}_{2} \mathrm{~m}^{-2} \mathrm{yr}^{-1}$ for CPT site, and $0.30 \mathrm{~N}_{2} \mathrm{O} \mathrm{m} \mathrm{yr}^{-1}, 18.86 \mathrm{~g}^{-2}$

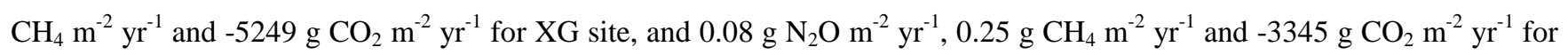
HMI site. The mean net exchanges of greenhouse gases between the mangrove ecosystem and atmosphere was $0.18 \mathrm{gN}_{2} \mathrm{O} \mathrm{m}$ $2 \mathrm{yr}^{-1}, 7.00 \mathrm{~g} \mathrm{CH}_{4} \mathrm{~m}^{-2} \mathrm{yr}^{-1}$ and $-4999 \mathrm{~g} \mathrm{CO}_{2} \mathrm{~m}^{-2} \mathrm{yr}^{-1}$ in Jiulong River Estuary.

Based on the annual emission rates from mangrove soils, the $\mathrm{CO}_{2}$-equivalent fluxes of $\mathrm{CO}_{2}, \mathrm{CH}_{4}$ and $\mathrm{N}_{2} \mathrm{O}$ were calculated to be 931, 238 and $53 \mathrm{~g} \mathrm{CO}_{2} \mathrm{~m}^{-2} \mathrm{yr}^{-1}$, respectively, in the mangrove wetlands (Table 3), and the warming effect of these greenhouse gases is equivalent to $1222 \mathrm{~g} \mathrm{CO}_{2} \mathrm{~m}^{-2} \mathrm{yr}^{-1}$. The two trace gases, $\mathrm{CH}_{4}$ and $\mathrm{N}_{2} \mathrm{O}$ comprised $19.5 \%$ and $4.3 \%$, respectively, of the total warming effect. When balancing the warming effect of the gases and the concurrent $\mathrm{CO}_{2}$ -

30 sequestration rate of the mangrove plants, the net effect of the mangrove ecosystem on atmospheric warming is estimated to 
Biogeosciences Discuss., doi:10.5194/bg-2015-662, 2016

Manuscript under review for journal Biogeosciences

Published: 10 February 2016

(c) Author(s) 2016. CC-BY 3.0 License.

be $-4708 \mathrm{~g} \mathrm{CO}_{2} \mathrm{~m}^{-2} \mathrm{yr}^{-1}$ (Table 4), further indicating the mangrove wetland as an affirmative role in mitigating global warming.

\section{Discussion}

Although numerous studies have characterized the $\mathrm{C}$ sequestration/bury in mangrove wetlands and their greenhouse gas

5 emissions, few have focused on the role of mangrove wetlands in mitigating atmospheric warming by considering both the plant $\mathrm{CO}_{2}$ sequestration and soil greenhouse gas emissions. The present study demonstrates that mangrove plants play an important role in mitigating atmospheric warming through their $\mathrm{CO}_{2}$ sequestration; however, mangrove soils on the other hand could be significant sources of greenhouse gases, and the warming effect of the gases emissions would reduce a large proportion of the vegetation benefit.

10 The soil to atmosphere gases fluxes in the Jiulong River Estuary fell within the ranges previously reported for other mangrove wetlands (Chauhan et al., 2008; Chen et al., 2010), and the results further demonstrate that mangrove soils can be sources of greenhouse gases. The greenhouse gases fluxes are related to mangrove soil properties, including concentrations of organic carbon, total and inorganic nitrogen, bulk density, salinity and redox potential (Purvaja and Ramesh, 2001; Allen et al., 2007; Chen et al., 2010, 2012), as microbial processes involved in the gases productions are regulated by the soil

15 characteristics. In addition to our previous studies in other subtropical K. obvota-dominated wetlands in South China (Chen et al., 2010), the greenhouse gases fluxes in Jiulong River Estuary also significantly increased with soil organic carbon, nitrogen and $\mathrm{NH}_{4}{ }^{+}-\mathrm{N}$ concentrations. Allen et al. (2007) suggested that the site-level control of $\mathrm{N}_{2} \mathrm{O}$ production in mangrove soils was attributed to nitrification when sediment had high ammonium levels and positive $\mathrm{E}_{\mathrm{h}}$ but to denitrification when sediment had high nitrate levels and negative $E_{h}$. The positive soil $E_{h}$ in the mangrove soil and significant correlation

20 between $\mathrm{N}_{2} \mathrm{O}$ flux and soil $\mathrm{NH}_{4}{ }^{+}-\mathrm{N}$ concentration therefore indicated the importance of nitrification process in mangrove soil responsible for the $\mathrm{N}_{2} \mathrm{O}$ production. Nevertheless, the results didn't exclude the potential of denitrification for $\mathrm{N}_{2} \mathrm{O}$ production as the soil $\mathrm{E}_{\mathrm{h}}$ in this study was below $350 \mathrm{mv}$, below which denitrification usually starts (Pitty, 1979). This is different from the previous study in Maipo mangrove, where denitrification was suggested to be the dominant mechanism for $\mathrm{N}_{2} \mathrm{O}$ production (Chen et al., 2012). The mangrove soil in this study had comparable or higher $\mathrm{NO}_{3}^{-}-\mathrm{N}$ concentration

25 compared with the Maipo mangrove but the $\mathrm{N}_{2} \mathrm{O}$ flux was much lower in Jiulong River Estuary. This could be attributed to the lower soil $\mathrm{E}_{\mathrm{h}}$ measured in Maipo (-158 to $56 \mathrm{mv}$ ), which was more favorable to denitrification, and further demonstrates the significance of denitrification in Maipo mangrove.

Methane emission from the coastal soils have been known to be limited by high salinity as the presence of high sulfate in coastal soils allows sulfate-reducing bacteria to outcompete methanogens for energy sources (Biswas et al., 2007;

30 Poffenbarger et al., 2011). The contrarily spatial variation in soil $\mathrm{CH}_{4}$ emissions to salinity in Jiulong River Estuary was also consistent to such inhibition effect, and lower $\mathrm{CH}_{4}$ flux was recorded in the HMI site with higher porewater salinity. The high soil $\mathrm{NH}_{4}{ }^{+}-\mathrm{N}$ concentration also enhanced the $\mathrm{CH}_{4}$ emission into the atmosphere in this study, similarly to some other 
Biogeosciences Discuss., doi:10.5194/bg-2015-662, 2016

Manuscript under review for journal Biogeosciences

Published: 10 February 2016

(c) Author(s) 2016. CC-BY 3.0 License.

studies (e.g. Allen et al., 2007; Chen et al., 2010), probably due to the inhibition effect of soil $\mathrm{NH}_{4}^{+}-\mathrm{N}_{\text {on }} \mathrm{CH}_{4}$ oxidation under high concentration (Bosse et al., 1993). Mangrove soils with more positive $\mathrm{E}_{\mathrm{h}}$ and longer exposure would lead to higher aerobic respiration and chemical oxidation of organic matter in soil, and are on the other hand unfavourable to $\mathrm{CH}_{4}$ emission. However, no significant correlations were found between soil $\mathrm{E}_{\mathrm{h}}$ and the gases fluxes in the present study, and the

$5 \mathrm{C}$ /nutrient availabilities were the most influencing factors. As the microbial mechanisms that driving the greenhouse gases productions are lacking in this study, more detailed studies on microbial processes involved in the gases emissions in the soil, e.g. methanogenesis, methane oxidation, nitrification and denitrification, and their interactions with soil abiotic factors are therefore needed and worthy further studies.

Similar to previous studies (e.g. Allen et al., 2011; Chen et al., 2010, 2012), gas fluxes in this region varied with mangrove

10 site and season. For instance, the $\mathrm{CO}_{2}$ flux ranged between as low as $307 \mathrm{~g} \mathrm{~m}^{-2} \mathrm{yr}^{-1}$ and up to $1470 \mathrm{~g} \mathrm{~m}^{-2} \mathrm{yr}^{-1}$. Even greater spatial variation was fould in $\mathrm{CH}_{4}$ flux. The spatial variations of gases fluxes could be partly attributed to the differences in soil organic carbon and nitrogen contents as the substrates for soil respiration among the study sites. Such spatial variation and the seasonal variation in gas fluxes, suggested to be mainly due to temperature in subtropical mangroves and moisture in tropical mangroves (Chen et al., 2012), therefore should be taken into account for inventory of greenhouse gas emissions.

15 Difference in the ecosystem mitigating effect were also found among the three mangrove sites, with a lower value occurring at $\mathrm{HMI}$ due to a much lower plant $\mathrm{CO}_{2}$ sequestration rate. The $\mathrm{XG}$ site had the highest $\mathrm{CO}_{2}$-equivalent flux of greenhouse gas emissions, which offset $33 \%$ of the plant $\mathrm{CO}_{2}$ capture rate, while this ratio was <10 \% in the HMI mangrove site. We also measured a lower primary production accompanied by low gas emission rates in this study. Similarly, the soil respiration rate was found to be correlated with litter fall production on a large range of latitude extending from $27^{\circ} \mathrm{N}$ to

$2037^{\circ} \mathrm{S}$ (Lovelock, 2008). This pattern suggested that the more $\mathrm{CO}_{2}$ is sequestrated by mangroves, the more substantial the effect of the soil greenhouse gas emissions might be, and their warming effect should not be ignored.

The subtropical $K$. obovata mangrove forest had high net primary productivity, close to amounts reported in tropical regions, and higher than the global mean production (Bouillon et al., 2008). This high NPP but low carbon gases emissions from soil indicated that the mangrove wetland in this area has strong sequestration capability of atmospheric carbon on the

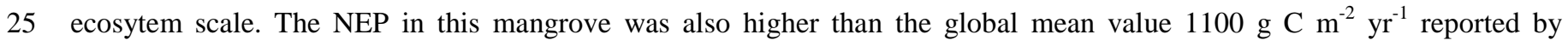
Bouillon et al. (2008), and those estimated in a Rhizophora mangle forest (561 $\mathrm{gC} \mathrm{m}^{-2} \mathrm{yr}^{-1}$ ) in Puerto Rico (Golley et al., 1962) and in the mangrove in western Florida Everglades (1170 $\mathrm{gC} \mathrm{m}^{-2} \mathrm{yr}^{-1}$ ) (Barr et al., 2010). Although $\mathrm{CH}_{4} \mathrm{emission} \mathrm{was}$ also significant $\left(7.0 \mathrm{~g} \mathrm{CH}_{4} \mathrm{~m}^{-2} \mathrm{yr}^{-1}\right.$, and up to $\left.3215 \mu \mathrm{g} \mathrm{m}^{-2} \mathrm{~h}^{-1}\right)$ in the estuarine mangrove wetlands in this study, it accounted for a unelectable proportion $(1.4 \%)$ of the soil gaseous carbon emission in this study.

30 The present study assessed the role of mangrove wetland in mitigating atmospheric warming effect, through direct quantification of the gaseous exchange between mangrove ecosystem and atmosphere. The annual gases emission rates were estimated from the fluxes from the exposed soil, and this estimation was subjected to the assumption that the wateratmosphere fluxes during inundation were similar to the soil-atmosphere fluxes during exposure. The assumption was based on the following findings from previous studies. Bouillon et al. (2008) reported that there was no significant difference in the 
Biogeosciences Discuss., doi:10.5194/bg-2015-662, 2016

Manuscript under review for journal Biogeosciences

Published: 10 February 2016

(c) Author(s) 2016. CC-BY 3.0 License.

$\mathrm{CO}_{2}$ emission between exposed and inundated periods although the processes of gases diffused from soil to water then to air was likely affected during the inundation period. A diurnal measurement of $\mathrm{CH}_{4}$ and $\mathrm{N}_{2} \mathrm{O}$ fluxes in an estuarine marsh in Fujian Province also showed no clear difference between the inundation and exposure periods (Tong et al., 2013). Moreover, the mangrove sites in this study locate in the mid to high intertidal zones, and the forest floor was not flooded by tides in most of the times (Chen et al., 2008). Therefore, the calculations of annual emissions from fluxes during exposure time should not affect the findings of the present study.

On the ecosystem scale, the mangrove wetland was small sources of $\mathrm{CH}_{4}$ and $\mathrm{N}_{2} \mathrm{O}$, compared to the significant $\mathrm{CO}_{2}$ sink. However, the warming effect of soil greenhouse gases emissions offset $22 \%$ of the plant $\mathrm{CO}_{2}$ sequestration rate in this study, and the net effect of the mangrove ecosystem on atmospheric warming effect was estimated to be $-4676 \mathrm{~g} \mathrm{CO}_{2} \mathrm{~m}^{-2} \mathrm{yr}^{-1}$. This

10 value was higher than the global value ( - $4000 \mathrm{~g} \mathrm{CO}_{2} \mathrm{~m}^{-2} \mathrm{yr}^{-1}$, without consideration of soil non-CO $\mathrm{Cases}$ emissions) calculated from the global NPP and soil respiration rates (Bouillon et al., 2008). Some other studies in saltmarshes also quantified the potential global warming feedbacks based on the soil carbon sequestration rate and non- $\mathrm{CO}_{2}$ gases emission rates (e.g. Chmura et al., 2011; Yuan et al., 2014). In case of the rapid soil accumulation rate in the mangrove wetland in Jiulong River Estuary (33.7 mol C m${ }^{-2} \mathrm{yr}^{-1}$, equivalent to $1482.8 \mathrm{~g} \mathrm{CO}_{2} \mathrm{~m}^{-2} \mathrm{yr}^{-1}$, Alongi et al., 2005), the global warming 15 potential of this mangrove area is calculated as $\sim 1190 \mathrm{~g} \mathrm{CO}_{2} \mathrm{~m}^{-2} \mathrm{yr}^{-1}$ (the $\mathrm{CO}_{2}$-equivelent flux of $\mathrm{CH}_{4}$ and $\mathrm{N}_{2} \mathrm{O}$ fluxes had a sum of $290 \mathrm{~g} \mathrm{CO}_{2} \mathrm{~m}^{-2} \mathrm{yr}^{-1}$, Table 3). This value was much higher than those reported in northern and northwestern Atlantic saltmarshes estimated in the growing season (574-1000 $\mathrm{g} \mathrm{CO}_{2} \mathrm{~m}^{-2} \mathrm{yr}^{-1}$, Chmura et al., 2011) and the marshes in eastern China (114-1130 $\mathrm{g} \mathrm{CO}_{2} \mathrm{~m}^{-2} \mathrm{yr}^{-1}$, Yuan et al., 2014). Unlike the salt marsh, which has been supposed that its carbon accumulation through plant growth is roughly balanced by losses through grazing, decomposition and fire, and no gain is

20 achieved (IPCC, 2006, 2014b), a majority of C captured by mangrove plant is stored in their biomass. Take these into account, it can be suggested that the mangrove wetland plays a more ecologically relevant role in mitigating global warming.

Despite their low fluxes compared to $\mathrm{CO}_{2}$, the contributions of the trace $\mathrm{CH}_{4}$ and $\mathrm{N}_{2} \mathrm{O}$ gases, when considering their warming effect, are also relevant to global warming in the mangrove wetland. When subjected to anthropogenic nutrient inputs, the emissions of these two gases and $\mathrm{CO}_{2}$, could be more considerable (Muñoz-Hincapié et al., 2002; Chen et al.,

25 2011, 2014), which would largely enhance their contributions to the warming effect. For instance, the annual mean fluxes of $\mathrm{CH}_{4}$ and $\mathrm{N}_{2} \mathrm{O}$ could be up to $3899 \mu \mathrm{g} \mathrm{CH}_{4} \mathrm{~m}^{-2} \mathrm{~h}^{-1}$ and $57.1 \mu \mathrm{g} \mathrm{N} \mathrm{O} \mathrm{m}^{-2} \mathrm{~h}^{-1}$, respectively, in the Brisbane mangrove, which receives discharge from a sewage treatment plant in Queensland, Australia (Allen et al., 2007). Even higher gas fluxes have been reported from mangrove soil, and $\mathrm{N}_{2} \mathrm{O}$ and $\mathrm{CH}_{4}$ contributed twice the global warming potential as $\mathrm{CO}_{2}$ in the Futian mangrove in South China which receives discharges and anthropogenic nutrient inputs from Pearl River Delta and nearby

30 polluted rivers (Chen et al., 2010). The emissions of $\mathrm{CH}_{4}$ and $\mathrm{N}_{2} \mathrm{O}$ from mangrove soils therefore should also be documented in addition to that of $\mathrm{CO}_{2}$ to quantify the contribution of greenhouse gases emissions from mangrove soil to global warming, especially for those receiving exogenous nutrients. Liu and Greaver (2009) have also suggested that although the addition of $\mathrm{N}$ increased the global terrestrial $\mathrm{C}$ sink, $\mathrm{CO}_{2}$ sequestration could be largely offset by $\mathrm{N}$ stimulation of global $\mathrm{CH}_{4}$ and $\mathrm{N}_{2} \mathrm{O}$ 
Biogeosciences Discuss., doi:10.5194/bg-2015-662, 2016

Manuscript under review for journal Biogeosciences

Published: 10 February 2016

(c) Author(s) 2016. CC-BY 3.0 License.

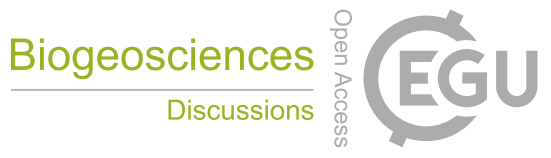

(c) (i)

emissions; and $\mathrm{N}_{2} \mathrm{O}$ was found to dominate the total warming effect of gases emissions in some agro-ecosystems (Mosier et al., 2005).

Mangrove ecosystem is open and dynamic in the carbon biogeochemical processes. In addition to the carbon gases exchanges, carbon exchanges between mangrove and the adjacent ecosystems include the burial of exogenous carbon, the

5 loss from mangrove ecosystem through production of dissolved organic and dissolved inorganic carbon when the soils are covered by water, and by loss of particulate organic carbon to coastal zone (Ye et al., 2011; Bouillon et al., 2008). These carbon balance and dynamics relate to the potential of mangrove wetland in reducing carbon gases emissions, therefore their involvements in the mitigation effect of wetlands on global warming deserve further studies.

\section{Conclusions}

10 The present study showed that mangrove soils are significant sources of greenhouse gases, and the warming effect of gases emissions could largely offset the benefit of plant $\mathrm{CO}_{2}$ sequestration to mitigating atmospheric warming. We therefore propose that any assessment of the direct mitigation of atmospheric warming should take into account soil greenhouse gas emissions as well as plant $\mathrm{CO}_{2}$ sequestration. The contributions of trace amounts of $\mathrm{CH}_{4}$ and $\mathrm{N}_{2} \mathrm{O}$ gases to the warming effect should not be ignored, especially in nutrient-enriched mangrove wetlands. Moreover, the temporal and spatial

15 variations in gas fluxes and plant $\mathrm{CO}_{2}$ sequestration should be taken into account to improve the accuracy of estimates of the mitigating effect of mangroves on atmospheric warming.

\section{Author contribution}

G. Chen designed the experiments, and S. Chen and D. Yu carried out the field sampling and laboratory analysis. B. Chen performed the data analysis. G. Chen wrote the first draft of the manuscript, and all authors contributed substantially to

20 revisions.

\section{Acknowledgements}

The work described in this paper was supported by the National Natural Science Foundation of China (41206108) and the Fujian Province Science and Technology Plan Project (2014Y0067). The 973 Program (2015CB452905) and Science Research Foundation of the Third Institute of Oceanography, SOA (2014011), also provided support. The authors have no 25 conflict of interest. The authors are grateful to Ms. Y.P. Chen, Dr. X.Q. Zheng and Mrs. Q.Y. Lin for their assistance with field sampling and laboratory analysis, as well as Mr. Z.Y. Xue for assistance with mangrove site selection. 
Biogeosciences Discuss., doi:10.5194/bg-2015-662, 2016

Manuscript under review for journal Biogeosciences

Published: 10 February 2016

(c) Author(s) 2016. CC-BY 3.0 License.

\section{References}

Adams, C.A., Andrews, J.E., and Jickells, T.: Nitrous oxide and methane fluxes vs. carbon, nitrogen and phosphorous burial in new intertidal and saltmarsh sediments, Sci. Total Environ., 434, 240-251, 2012.

Allen, D.E., Dalal, R.C., Rennenberg, H., Meyer, R.L., Reeves, S., and Schmidt, S.: Spatial and temporal variation of nitrous oxide and methane flux between subtropical mangrove sediments and the atmosphere, Soil Biol. Biochem., 39, 622-631, 2007.

Allen, D., Dalal, R.C., Rennenberg, H., and Schmidt, S.: Seasonal variation in nitrous oxide and methane emissions from subtropical estuary and coastal mangrove sediments, Australia, Plant Biol., 13, 126-133, 2011.

Alongi, D.M., Pfitzner, J., Trott, L.A., Tirendi, F., and Klumpp, D.W.: Rapid sedimentation and microbial mineralization in mangrove forests of the Jiulongjiang estuary, China, Estuar. Coast. Shelf Sci., 63, 605-618, 2005.

Alongi, D.M.: The Energetics of Mangrove Forests, Springer Verlag Press, London, 2009.

Barr, J.G., Engel,V., Fuentes, J.D., Zieman, J.C., O’Halloran, T.L., Smith III, T.J., and Anderson, G.H.: Controls on mangrove forest-atmosphere carbon dioxide exchanges in western Everglades National Park, J. Geophys. Res., 115, G02020, 2010.

15 Bauza, J., Morell, J.M., and Corredor, J.E: Biogeochemistry of nitrous oxide production in the red mangrove (Rhizophora mangle) forest soils. Estuar. Coast. Shelf Sci., 55, 697-704, 2002.

Biswas, H., Mukhopadhyay, S.K., Sen, S., and Jana, T.K.: Spatial and temporal patterns of methane dynamics in the tropical mangrove dominated estuary, NE coast of Bay of Bengal, India, J. Mar. Syst., 68, 55-64, 2007.

Bosse, U., Frenzer, P., and Conrad, R.: Inhibition of methane oxidation by ammonium in the surface layer of a littoral sediment, FEMS Microbiol. Ecol., 13, 123-34, 1993.

Bouillon, S., Borges, A.V., Castañeda-Moya, E., Diele, K., Dittmar, T., Duke, N.C., Kristensen, E., Lee, S.Y., Marchand, C., Middelburg, J.J., Rivera-Monroy,V.H., Thomas J. Smith III, T.J., and Twilley, R.R.: Mangrove production and carbon sinks: a revision of global budget estimates, Global Biogeochem. Cycles, 22, GB2013, 2008.

Chen, G.C., Tam, N.F.Y., and Ye, Y.: Summer fluxes of atmospheric greenhouse gases $\mathrm{N}_{2} \mathrm{O}, \mathrm{CH}_{4}$ and $\mathrm{CO}_{2}$ from mangrove soil in South China, Sci. Total Environ., 408, 2761-2767, 2010.

Chen, G.C., Tam, N.F.Y., Wong, Y.S., and Ye, Y.: Effect of wastewater discharge on greenhouse gas fluxes from mangrove soils, Atmos. Environ., 45, 1110-1115, 2011.

Chen, G.C., Tam, N.F.Y., and Ye, Y.: Spatial and seasonal variations of atmospheric $\mathrm{N}_{2} \mathrm{O}$ and $\mathrm{CO}_{2}$ fluxes from a subtropical mangrove swamp and their relationships with soil characteristics, Soil Biol. Biochem., 48, 175-181, 2012.

30 Chen, G.C., Tam, N.F.Y., and Ye, Y.: Does zinc in livestock wastewater reduce nitrous oxide $\left(\mathrm{N}_{2} \mathrm{O}\right)$ emissions from mangrove soils? Water Res., 65, 402-413, 2014.

Chen, G.C., Ye, Y., and Lu, C.Y., Seasonal variability of leaf litter removal by crabs in a Kandelia candel mangrove forest in Jiulongjiang Estuary, China, Estuar. Coast. Shelf Sci., 79, 701-706, 2008. 
Biogeosciences Discuss., doi:10.5194/bg-2015-662, 2016

Manuscript under review for journal Biogeosciences

Published: 10 February 2016

(c) Author(s) 2016. CC-BY 3.0 License.

Chauhan, R., Ramanathan, A.L., and Adhya, T.K.: Assessment of methane and nitrous oxide flux from mangroves along Eastern coast of India, Geofluids, 8, 321-32, 2008.

Chmura, G.L., Kellman, L., and Guntenspergen, G.R.: The greenhouse gas flux and potential global warming feedbacks of a northern macrotidal and microtidal salt marsh, Environ. Res. Lett., 6, 044016, 2011.

5 Corredor, J.E., Morell, J.M., and Bauz, J.: Atmospheric nitrous oxide fluxes from mangrove soils. Mar. Pollut. Bull., 3, 473$478,1999$.

Dittmar, T., Hertkorn, N., Kattner, G., and Lara, R.J.: Mangroves, a major source of dissolved organic carbon to the oceans, Global Biogeochem. Cycles, 20, GB1012, 2006.

Duarte, C.M., Middelburg, J.J., and Caraco, N.: Major role of marine vegetation on the oceanic carbon cycle, Biogeosciences, $2,1-8,2005$.

Golley, F., Odum, H.T., and Wilson, R.F.: The structure and metabolism of a Puerto Rican red mangrove forest in May. Ecology, 43, 9-19, 1962.

IPCC: 2006 IPCC guideline for national greenhouse gas inventory, Prepared by the National Greenhouse Gas Inventories Programme, Eggleston HS, Buendia L, Miwa K, Ngara T and Tanabe K (eds). IGES, Japan, 2006.

15 IPCC: Climate Change 2014: Synthesis Report. Contribution of Working Groups I, II and III to the Fifth Assessment Report of the Intergovernmental Panel on Climate Change [Core Writing Team, R.K. Pachauri and L.A. Meyer (eds.)]. IPCC, Geneva, Switzerland, 2014a.

IPCC: 2013 Supplement to the 2006 IPCC guideline fir national greenhouse gas inventories: wetland, Hiraishi, T., Krug, T.,

Tanabe, K., Srivastava, N., Baasansuren, J., Fukuda, M., and Troxler, T.G. (eds). IPCC, Switzerland, $2014 b$.

20 Kreuzwieser, J., Buchholz, J., and Rennenberg, H: Emission of methane and nitrous oxide by Australian mangrove ecosystems, Plant Biol., 5, 423-431, 2003.

Komiyama, A., Ong, J.E., and Poungparn, S.: Allometry, biomass, and productivity of mangrove forests: a review, Aquat. Bot., 89, 128-137, 2008.

Lee, S.Y.: Primary productivity and particulate organic matter flow in an estuarine mangrove-wetland in Hong Kong, Mar. Biol., 106, 453-463, 1990.

Lin, P., Lu, C.Y., Lin, G.H., Chen, R.H., and Su, L.: Studies on mangrove ecosystem of Jiulongjiang River Estuary in China I. The biomass and productivity of Kandelia candel community, J. Xiamen Univ. Nat. Sci. 24, 508-514, 1985. (In Chinese)

Liu, L. and Greaver, T.L.: A review of nitrogen enrichment effects on three biogenic GHGs: the $\mathrm{CO}_{2}$ sink may be largely offset by stimulated $\mathrm{N}_{2} \mathrm{O}$ and $\mathrm{CH}_{4}$ emission, Ecol. Lett., 12, 1103-1117, 2009.

30 Lovelock, C.E.: Soil respiration and belowground carbon allocation in mangrove forests, Ecosystems, 11, 342-354, 2008.

Magenheimer, J.F., Moore, T.R., Chmura, G.L., and Daoust, R.J.: Methane and carbon dioxide flux from a macrotidal salt marsh, Bay of Fundy, NewBrunswick, Estuaries, 19, 139-145, 1996. 
Biogeosciences Discuss., doi:10.5194/bg-2015-662, 2016

Manuscript under review for journal Biogeosciences

Published: 10 February 2016

(c) Author(s) 2016. CC-BY 3.0 License.

Mcleod, E., Chmura, G.L., Bouillon, S., Salm, R., Björk, M., Duarte, C.M., Lovelock, C.E., Schlesinger, W.H., and Silliman, B.R.: A blueprint for blue carbon: toward an improved understanding of the role of vegetated coastal habitats in sequestering $\mathrm{CO}_{2}$, Front. Ecol. Environ., 9, 552-560, 2011.

Morris, J.T., and Whiting, G.J.: Emission of gaseous carbon dioxide from salt-marsh sediments and its relation to other carbon losses, Estuaries, 9, 9-19, 1986.

Moseman-Valtierra, S., Gonzalez, R., Kroeger, K.D., Tang, J., Chao, W.C., Crusius, J., Bratton, J., Green, A., and Shelton, J.: Short-term nitrogen additions can shift a coastal wetland from a sink to a source of $\mathrm{N}_{2} \mathrm{O}$, Atmos. Environ., 45, 4390-4397, 2011.

Mosier, A.R., Halvorson, A.D., Peterson, G.A., Robertson, G.P., and Sherrod, L.: Measurement of net global warming potential in three agroecosystems, Nutr. Cycl. Agroecosys., 72, 67-76, 2005.

Muñoz-Hincapié, M., Morell, J.M., and Corredor, J.E.: Increase of nitrous oxide flux to the atmosphere upon nitrogen addition to red mangroves sediments, Mar. Pollut. Bull., 44, 992-996, 2002.

Myhre, G., Shindell, D., Bréon, F.-M., Collins, W., Fuglestvedt, J., Huang, J., Koch, D., Lamarque, J.-F., Lee, D., Mendoza, B., Nakajima, T., Robock, A., Stephens, G., Takemura T., and Zhang, H.: Anthropogenic and natural radiative forcing, in: Climate Change 2013: the Physical Science Basis Contribution of Working Group I to the Fifth Assessment Report of the Intergovernmental Panel on Climate Change (eds. Stocker, T.F., Qin, D., Plattner, G.K., Tignor, M., Allen, S.K., Boschung, J., Nauels, A., Xia, Y., Bex V., and Midgley P.M.), Cambridge University Press, Cambridge, 2013.

Odum, W.E., McInvor, C.C., and Smith III, T.J.: The Ecology of the Mangroves of South Florida: a Community Profile, United States Fish and Wildlife Service, Office of Biological Services, Washington D.C., 1982.

20 Page, A.L., Miller, R.H., and Keeney, D.R. (Eds.): Methods of Soil Analysis Part 2 Chemical and Microbiological Properties, Wisconsin, USA: American Society of Agronomy, 1982.

Pitty, A.F. (Ed.): Geography and Soil Properties, Methuen, London, pp. 188, 1979.

Poffenbarger, H.J., Needelman, B.A., and Megonigal, P.J.: Salinity influence on methane emissions from tidal marshes, Wetlands, 31, 831-842, 2011.

25 Purvaja, R. and Ramesh, R.: Natural and anthropogenic methane emission from coastal wetlands of South India. Environ. Manage., 27, 547-57, 2011.

Teas, H.J.: Silviculture with saline water, in: The Biosaline Concept (eds. Hollaender, A., Aller, J.C., Epstein, E., Pietro, A.S. and Zaborsky, O.R.), Springer, New York, 1979.

Tomlinson, P.B.: The Botany of Mangrove. Cambridge University Press, Cambridge, 1986.

30 Tong, C., Huang, J.F., Hu, Z.Q., and Jin, Y.F.: Diurnal variations of carbon dioxide, methane, and nitrous oxide vertical fluxes in a subtropical estuarine marsh on neap and spring tide days. Estuar. Coast., 36, 633-642, 2013.

Ye, Y., Pang B., Chen, G., and Chen, Y.: Processes of organic carbon in mangrove ecosystems, Acta Ecol. Sin., 31, 169-173, 2011. 
Biogeosciences Discuss., doi:10.5194/bg-2015-662, 2016

Manuscript under review for journal Biogeosciences

Published: 10 February 2016

(c) Author(s) 2016. CC-BY 3.0 License.

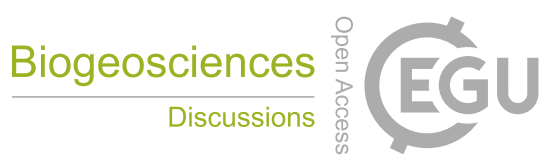

(c) (i)

Yuan, J., Ding, W., Liu, D., Kang, H., Freeman, C., Xiang, J., and Lin, Y.: Exotic Spartina alterniflora invasion alters ecosystem-atmosphere exchange of $\mathrm{CH}_{4}$ and $\mathrm{N}_{2} \mathrm{O}$ and carbon sequestration in a coastal salt marsh in China, Global Change Biol., doi: 10.1111/gcb.12797, 2014.

Zheng, W.J., Xue, X., and Lin, P.: Studies on dynamics of carbon, hydrogen and nitrogen elements for Kandelia candel mangrove community in Fujian, China, Acta Ecol. Sin., 15, 229-234, 1995. 
Biogeosciences Discuss., doi:10.5194/bg-2015-662, 2016

Manuscript under review for journal Biogeosciences

Published: 10 February 2016

(c) Author(s) 2016. CC-BY 3.0 License.

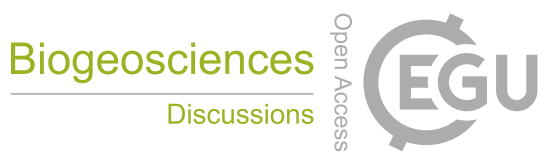

(c) (i)

Table 1. Litter fall production and net primary production $\left(\mathrm{gDW} \mathrm{m} \mathrm{yr}^{-1}\right)$ in the three mangrove sites in Jiulong River Estuary.

\begin{tabular}{cccccc}
\hline Mangrove & Leaf & Twig & Re-production & Total & NPP \\
\hline CPT & $683 \pm 101 \mathrm{a}$ & $241 \pm 105 \mathrm{a}$ & $641 \pm 234 \mathrm{a}$ & $1565 \pm 246 \mathrm{a}$ & $4306 \pm 676 \mathrm{a}$ \\
XG & $692 \pm 86 \mathrm{a}$ & $267 \pm 164 \mathrm{a}$ & $458 \pm 177 \mathrm{a}$ & $1417 \pm 189 \mathrm{a}$ & $3899 \pm 519 \mathrm{a}$ \\
HMI & $275 \pm 121 \mathrm{~b}$ & $52 \pm 72 \mathrm{~b}$ & $444 \pm 160 \mathrm{a}$ & $771 \pm 143 \mathrm{~b}$ & $2119 \pm 393 \mathrm{~b}$ \\
Mean & 550 & 187 & 514 & 1251 & 3441
\end{tabular}

CPT: Caoputou; XG: Xiaguo; HMI: Haimen Island; NPP: Net primary production. Different letters in one column indicate a significant difference among the three mangrove sites.

5 
Biogeosciences Discuss., doi:10.5194/bg-2015-662, 2016

Manuscript under review for journal Biogeosciences

Published: 10 February 2016

(c) Author(s) 2016. CC-BY 3.0 License.

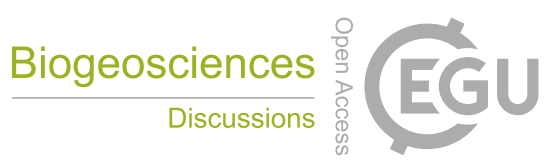

(c) (i)

Table 2. Pearson correlation coefficient values (r) between soil properties and summer fluxes of greenhouse gases in Jiulong

River Estuary.

\begin{tabular}{cccc}
\hline Soil parameter & \multicolumn{3}{c}{ Fluxes of gases } \\
\cline { 2 - 4 } & $\mathrm{N}_{2} \mathrm{O}$ & $\mathrm{CH}_{4}$ & $\mathrm{CO}_{2}$ \\
\hline Redox potential & -0.323 & -0.126 & -0.130 \\
Water content & 0.424 & 0.329 & 0.175 \\
$\mathrm{NH}_{4}{ }^{-} \mathrm{N}$ & $0.575^{*}$ & $0.730^{* *}$ & $0.618^{*}$ \\
$\mathrm{NO}_{3}{ }^{-} \mathrm{N}$ & -0.199 & 0.008 & -0.205 \\
$\mathrm{OC}$ & $0.756^{* * *}$ & $0.838^{* * *}$ & $0.713^{* *}$ \\
$\mathrm{TKN}$ & $0.812^{* * *}$ & $0.541^{*}$ & $0.724^{* *}$
\end{tabular}

$*, * *$ and $* * *$ indicate significant $\mathrm{r}$ value at $\mathrm{p}<0.05,001$ and 0001 , respectively $(\mathrm{n}=18)$. 
Biogeosciences Discuss., doi:10.5194/bg-2015-662, 2016

Manuscript under review for journal Biogeosciences

Published: 10 February 2016

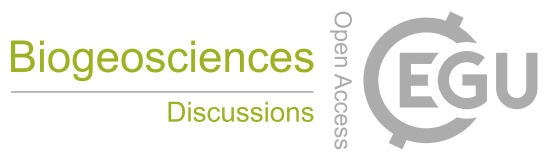

(C) Author(s) 2016. CC-BY 3.0 License.

(c) (i)

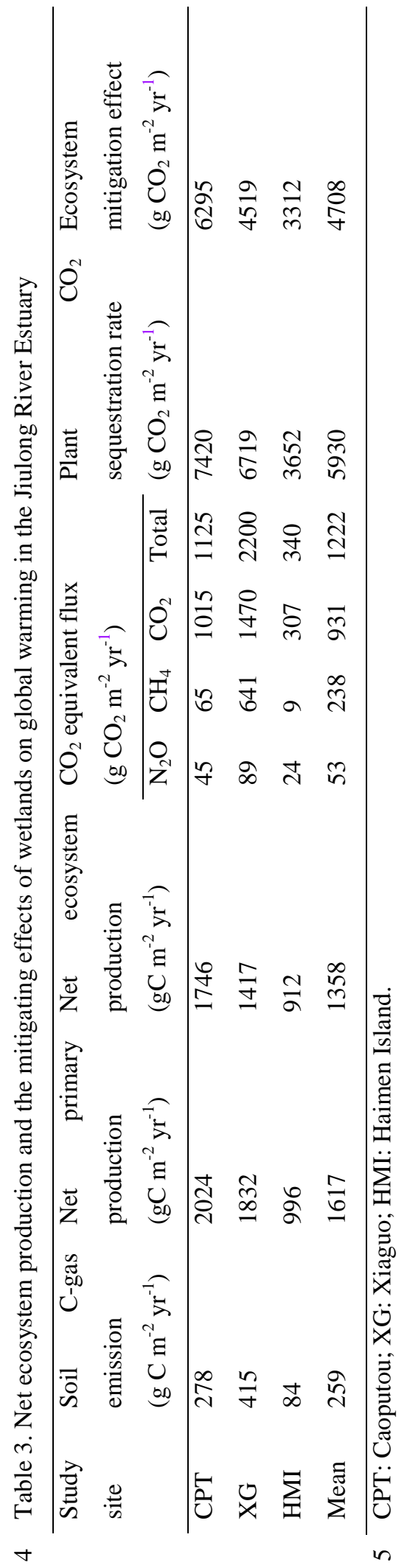


Biogeosciences Discuss., doi:10.5194/bg-2015-662, 2016

Manuscript under review for journal Biogeosciences

Published: 10 February 2016

(c) Author(s) 2016. CC-BY 3.0 License.

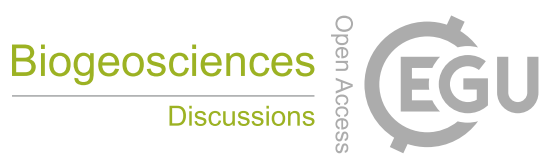

(c) (i)

\section{Figure captions}

7 Fig. 1 Map of the Jiulong River Estuary, China. Numbers 1-3 indicate the positions of the three sampling sites in this study.

8 1: Caoputou; 2: Xiaguo; 3: Haimen Island.

9 Fig. 2 Soil to atmosphere greenhouse gas flux at the mangrove sites in Jiulong River Estuary. Same abbreviation as Fig. 1. In 10 each season, different letters (in lower case) indicated significant difference among the three mangrove sites according to 11 ANOVA test. For each mangrove site, different letters (in capital) indicated significant difference among the four seasons.

12 Fig. 3 Soil characteristics at the mangrove sites in Jiulong River Estuary. Same abbreviation as Fig. 1. Different letters 13 indicated significant difference among the three mangrove sites according to ANOVA test.

14 
Biogeosciences Discuss., doi:10.5194/bg-2015-662, 2016

Manuscript under review for journal Biogeosciences

Published: 10 February 2016

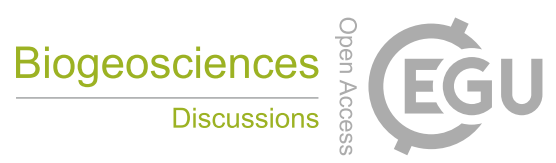

(c) Author(s) 2016. CC-BY 3.0 License.

(c) ${ }_{\mathrm{BV}}$

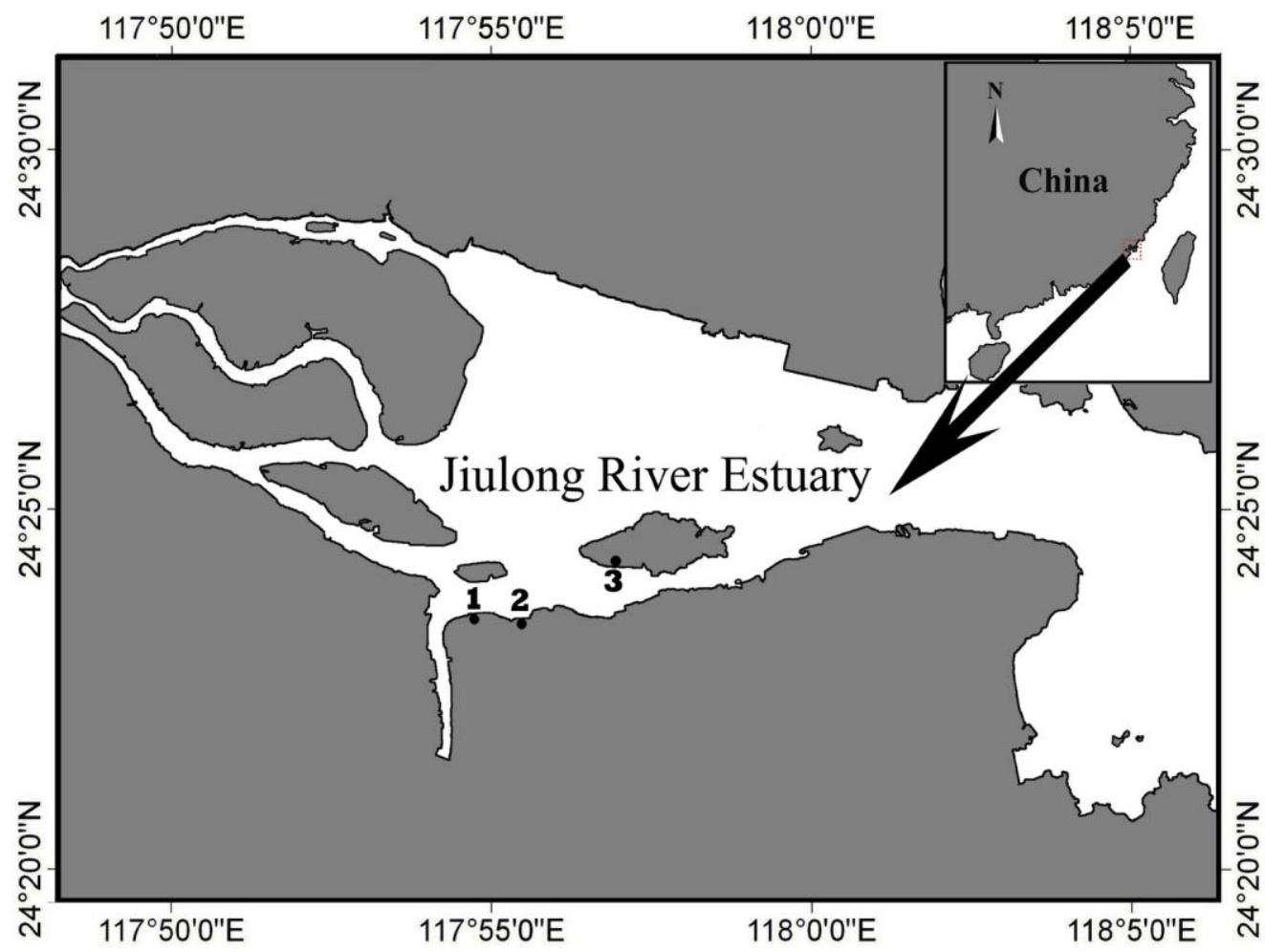

Fig. 1 
Biogeosciences Discuss., doi:10.5194/bg-2015-662, 2016

Manuscript under review for journal Biogeosciences

Published: 10 February 2016

(C) Author(s) 2016. CC-BY 3.0 License.
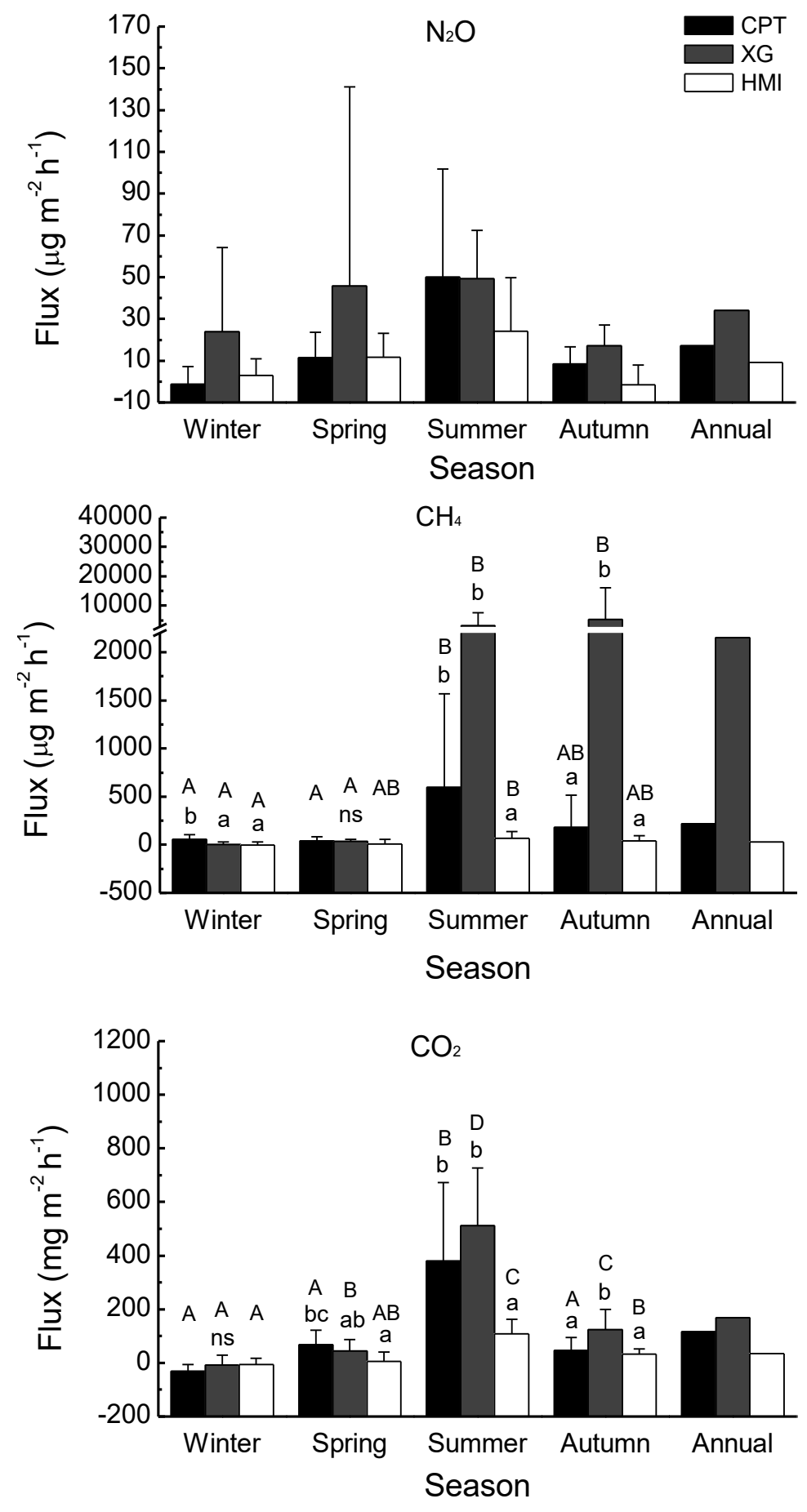

Fig. 2 
Biogeosciences Discuss., doi:10.5194/bg-2015-662, 2016

Manuscript under review for journal Biogeosciences

Published: 10 February 2016

(c) Author(s) 2016. CC-BY 3.0 License.
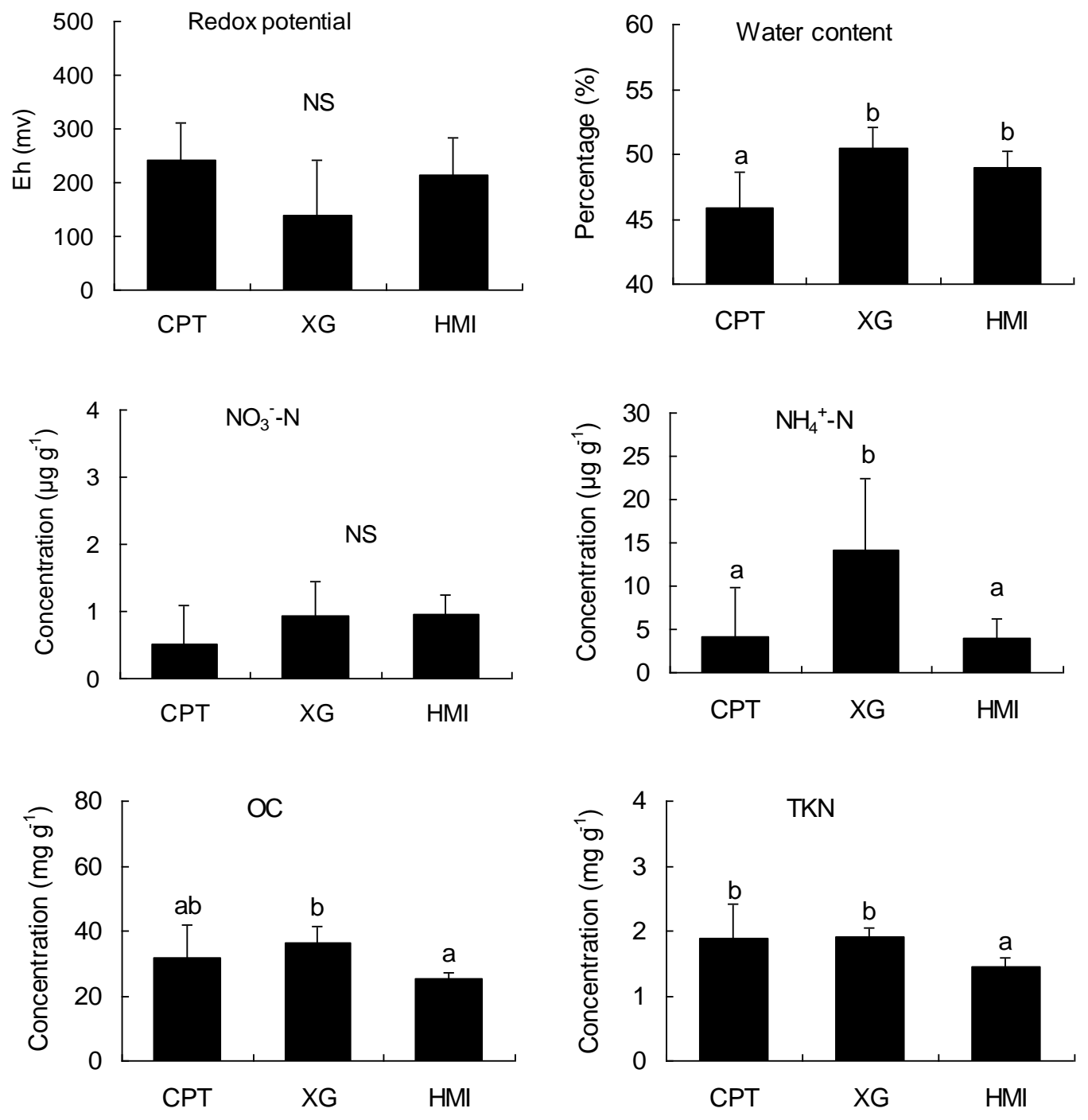

Fig. 3 